\title{
Market Funds and Trust-Investment Law
}

\author{
John H. Langbein and Richard A. Posner*
}

\section{INTRODUCTION}

There is growing interest within the investment community in what are known as "index" or "market" funds. These are mutual or other investment funds that have abandoned the traditional attempt to "beat the market" by picking and choosing among securities-buying stocks or bonds that they believe to be undervalued and selling those they believe to be overvalued. Instead, they create and hold essentially unchanged a portfolio of securities that is designed to approximate some index of market performance such as the Standard \& Poor's 500. The S\&P 500 is a hypothetical portfolio consisting of 500 major nonfinancial companies on the New York Stock Exchange weighted by the market value of each company's total outstanding shares. Batterymarch Financial Management Corporation in its Market Portfolio holds a 250-stock selection from the S\&P 500 designed to track the performance of the S\&P 500 very closely. Two major banks, American National Bank and Trust Company of Chicago and Wells Fargo Bank, have created market funds in their trust departments. And several large pension funds, including those of several Bell Telephone Companies and of Exxon, have recently placed a portion of their assets in such funds.

The rise of the market fund reflects growing dissatisfaction with the performance of conventional investment funds, which sacrifice diversification and incur heavy research and transaction costs in an apparently

\footnotetext{
*Professors of Law, University of Chicago, and Affiliated Scholars, American Bar Foundation. The authors want to thank Alexis Belash, Fischer Black, David Booth, Kenneth Dam, Lewis Dembitz, Gareth Jones, Spencer Kimball, Edmund Kitch, James Lorie, Bernard Meltzer, Daniel Meltzer, Byron Miller, Evan Schulman, and Rex Sinquefield (and his colleagues at American National Bank and Trust Company of Chicago) for their helpful comments on a previous draft of this article and/or conversations about the subject matter of the article, and the American Bar Foundation for financial support. The views expressed are those of the authors, not the Foundation.
} 
vain effort to outperform the broad market indices such as the S\&P $500{ }^{1}$ We shall examine in a little while the basis for this disillusionment with conventional investment management. For now it is sufficient to note that the disillusionment exists, seems to be on the increase, and has given impetus to the market-fund approach.

An important question, and the focus of this article, is the extent to which a trustee may invest in a market fund without thereby violating the legal standards that govern the investment of trust assets. ${ }^{2}$ The question is a particularly timely one in view of the new pension reform law. That law not only appears to impose on pension funds the traditional limitations governing trust investments ${ }^{3}$ but also forbids the waiver of these limitations. ${ }^{4}$ In the case of ordinary trusts the limitations that the law places on trust investments are often not terribly important, because they are waivable by the trust instrument and commonly are waived. But the pension reform law does not permit waivers. Therefore, it becomes critically important to determine the requirements of trust law with respect to investment in market funds.

1. As one example of this disillusionment we quote the following passage from a New York Times article, "Investing in the Averages" (April 29, 1973, Bus. Sec., p. 1, cols. 1-5):

In February, the American Telephone and Telegraph Company reported that for almost the last six years the portion of its \$10-billion pension fund managed by 31 banks had increased at about 8 per cent a year compared to about a 9 per cent increase in the Standard \& Poor's average of 500 stocks.

Was A.T.\&T. miffed at its bank advisers for their sub-par performance? Not at all.

"We are satisfied that we are doing as well as other large pools of capital," said John F. Thompson, A.T.\&T.'s director of pension-fund administration.

"Though it is defeatist not to try, because of A.T.\&T.'s large pool of capital, I think it is unrealistic to expect to outperform the averages," Mr. Thompson added.

Since the article appeared, some of A.T.\&T.'s operating subsidiaries have, as mentioned in the text, begun placing some pension-fund assets in a market fund.

2. For previous discussions of this question see Richard A. Posner, Economic Analysis of Law 195-98 (Boston, 1973); Note, Trustee Investment Powers: Imprudent Application of the Prudent Man Rule, 50 Notre Dame Lawyer 519 (1975); Note, Fiduciary Standards and The Prudent Man Rule Under the Employment [sic] Retirement Income Security Act of 1974, 88 Harv. L. Rev. 960 (1975); cf. Note, The Regulation of Risky Investments, 83 Harv. L. Rev. 603 (1970).

3. Section 404(a)(1)(B) of the Employee Retirement Income Security Act of 1974, 1 U.S. Cong. \& Adm. News '74, 944 (ERISA), requires the pension fund to be administered "with the care, skill, prudence, and diligence under the circumstances then prevailing that a prudent man acting in a like capacity and familiar with such matters would use in the conduct of an enterprise of a like character and with like aims." This is very similar to the "prudent man" rule of traditional trust law, see pp. 19-20, 24-28 infra. It has been argued, however, that the Act should not be interpreted as incorporating the "prudent man" rule of the traditional law in view of certain differences between pension and conventional trusts (see Note, Fiduciary Standards, supra note 2, at 965-69), which we discuss infra pp. 33-34.

4. See ERISA secs. 404(a)(1)(D), 410(a); cf. Note, Fiduciary Standards, supra note 2, at 968-69. 
Part I of this article describes briefly the evolution of trust law as it relates to the trustee's investment duties. Part II considers the evidence for regarding market-fund investment as superior to the conventional investment strategies that a trustee might follow. Part III demonstrates that the existing law of trusts is sufficiently flexible to permit the investment of trust assets in an appropriate market fund, despite the relative novelty of this investment vehicle. Part IV considers specific market-fund investment vehicles that might be suitable for trust investment.

\section{THE DEVELOPMENT OF THE LAW GOVERNING THE TRUSTEE'S INVESTMENT POWERS}

In 1719 the British Parliament authorized trustees to invest in the shares of the South Sea Company. ${ }^{5}$ The South Sea "Bubble" burst the next year, share prices fell by 90 percent, and "public confidence in joint stock companies and their securities was destroyed" for the rest of the eighteenth century.

In the period of reaction to the Bubble the standard of prudence in trust investment acquired three notable characteristics. First, the Court of Chancery developed a "court-list" of presumptively proper investment." The courts "repeatedly decided" that "the trustee would be free from liability if he invested . . . in Government three per cent stock [i.e., bonds]."s Some chancellors recognized "well-secured" first mortgages on realty as appropriate, ${ }^{9}$ although others questioned them well into the nineteenth century. ${ }^{10}$ Statutes extended the categories of presumptively proper investments. Lord St. Leonards' Act added East India stock to the court list and confirmed mortgage investments, "provided that such Investment shall in other respects be reasonable and proper."1 1 Successive Parliaments added various local and colonial government issues, and in 1889 certain railway debentures and preferred

5. 6 Geo. 1, c. 4 , secs. 23 (1719). 1969).

6. Laurence C. B. Gower, The Principles of Modern Company Law 31 (3d ed. London,

7. George G. Bogert \& George T. Bogert, The Law of Trusts and Trustees secs. 613-14 (2d ed. Kansas City, Mo., 1960) [hereinafter cited as Bogert, Trusts] ; A. H. Oosterhoff, Trustees' Powers of Investment: A Study Prepared at the Direction of the Ontario Law Review Commission 6ff. (1970).

8. George W. Keeton, The Law of Trusts 248 (9th ed. London, 1968).

9. Pocock v. Reddington, 5 Ves. 794, 800, 31 Eng. Rep. 862, 864 (1801) (Arden, M. R.). Earlier chancellors had vacillated on the question; see Keeton, supra note 8.

10. Raby v. Ridehalgh, 7 De G.M. \& G. 104, 44 Eng. Rep. 41 (Ch. Ap. 1855). See generally 3 Austin W. Scott, The Law of Trusts sec. 227.7, at 1818 (3d ed. Boston, 1967) [hereinafter cited as Scott, Trusts] .

11. $22 \& 23$ Vict., c. 35 , sec. 32 (1859). 
stocks. ${ }^{12}$ Most American jurisdictions maintained similar statutory lists into the 1940 s, and a variety survive to this day. ${ }^{13}$

Second, because investments not on the list were improper unless authorized in the trust instrument, England and many American jurisdictions forbade all trust investment in the securities of private enterprises until late in the nineteenth century, and greatly restricted such investment thereafter. Even today, the constitutions of Alabama and Montana forbid their legislatures to authorize trust investment in corporate issues. ${ }^{14}$

Third, trust-investment law developed a preoccupation with the preservation of the corpus (principal) of the trust. In the words of a leading case, "the primary object to be attained by a trustee in the matter of investing the funds confided to his control is their safety." 5 Even in Massachusetts, which had a general "prudent investor" rule rather than court or statutory lists and which permitted investment in corporate securities, it was emphasized that the rule "eschews the exuberance of the speculator." 16

What emerged, in short, was an emphasis on "safe" investments, a category dominated in the mind of the judges and legislators by long-term fixed-return obligations such as mortgages and bonds. This approach to investment by trustees may have made sense in the eighteenth and nineteenth centuries in light of two facts which are not true today. First, the capital markets were relatively undeveloped and the opportunities to make passive, reasonably liquid investments in common stock were therefore limited. Second, there was relatively little inflation in the eighteenth and nineteenth centuries. ${ }^{17}$ Although the interest rate on a fixed-income security will include the anticipated rate of inflation, the investor bears the risk-which in an inflationary period is substantial for long-term instruments-that the actual rate of inflation will turn out to be higher than the anticipated rate.

12. George W. Keeton, Modern Developments in the Law of Trusts $48-49$ (Belfast, 1971).

13. See the compilation in Mayo A. Shattuck, The Development of the Prudent Man Rule for Fiduciary Investment in the United States in the Twentieth Century, 12 Ohio State L.J. $491,502-4$ (1951). See also Oosterhoff, supra note 7, at 232-44. Current state laws are compiled in the text and pocket part of Bogert, Trusts secs. 616-63.

14. See Bogert, Trusts secs. 616,640 .

15. In re Estate of Cook, 20 Del. Ch. 123, 125, 171 A. 730 (1934), cited in 3 Scott, Trusts sec. 227 , at 1807 .

16. Kimball v. Whitney, 233 Mass. 321, 331, 123 N.E. 665, 666 (1919).

17. At the outbreak of World War I the price level in Britain was at about the same level as in the year 1660. There had been some inflation during the Napoleonic Wars but it had been followed by deflation. Phyllis Deane \& W. A. Cole, British Economic Growth 1688-1959: Trends and Structure 12-18 \& chart following 350 (2d ed. Cambridge, England: The University 
The law of trusts has been adjusting to changing conditions, but slowly. ${ }^{18}$ The English still have a statutory list; only in 1961 was it amended to permit half of the trust corpus to be invested in equities. ${ }^{19}$ Under pressure from the American Bankers Association, the majority of our states have since 1940 enacted the Model Prudent Man Investment Act, and others have reached a similar position through independent legislation or court decision. ${ }^{20}$ The Model Act, which follows Massachusetts law, dispenses with both the statutory list and the prohibition on investment in corporate issues. But it forbids investment "for the purpose of speculation" and directs trustees to consider "the probable income, as well as the probable safety, of their capital." Thus the position of the modern American law is that equities may be prudent investments if they are not "speculative," whatever that means.

England and the various American jurisdictions would not have clung to the traditional standards for such a long time had those standards been mandatory. Because trust settlors can vary the otherwise applicable law, lawyers and corporate fiduciaries have fitted most trust instruments with permissive investment powers. For most of the present century, therefore, the law has imposed the traditional standards largely on the beneficiaries of those trust settlors who failed to hire competent counsel.

Department of Applied Economics, 1969). Writing in 1960 and unaware of the enormous inflation that lay ahead, the authors said (at 17-18):

For those accustomed to the twentieth-century trends, however, the most striking implication of the earlier price data is the relative stability of the value of money.... Indeed, if we exclude the French wars and their immediate aftermath we can trace the index back to the Restoration without finding an annual reading which was more than a third above or below the 1913 level. The twentieth-century experience has been of an altogether different kind.... By 1959 retail prices were about four and a half times their level in 1913 and about seven times the low point of 1895.

18. Conflicts of interest have evidently played some role in the development and persistence of the antiquated court and statutory lists. The English chancellor was a high political officer of the government, perhaps not really so doubtful about "the soundness of other investment," but concerned "to provide a broad market for government securities ...." 3 Scott, Trusts sec. 227.4, at 1813. American state legislatures are also, it would seem, influenced by political considerations: their statutory lists authorize state and local obligations and the issues of favored corporations. See, e.g., Va. Code sec. 26-40(9), authorizing "[s] tocks, bonds and other securities of the Richmond, Fredericksburg and Potomac Railroad Company ...."

19. The Trustee Investments Act of $1961,9 \& 10$ Eliz. 2, c. 62 , is conveniently reprinted for American readers in Bogert, Trusts sec. 615 (Supp. 1975). For discussion see Keeton, supra note 12 , at $55 \mathrm{ff}$.; Oosterhoff, supra note 7 , at $49 \mathrm{ff}$.

20. See the text of the Act in Shattuck, supra note 13, at 508-9; Oosterhoff, supra note 7, at 229-31; and as the enacted law of particular states, e.g., Maine Rev. Stat. ch. 160, secs. 18-21, in Bogert, Trusts sec. 633. ERISA-which preempts state law insofar as pension funds subject to ERISA are concerned (sec. 514)-appears to have adopted the basic standard of the Model Act (see note 3 supra). 
Nevertheless, those standards continue to haunt even the most carefully drafted professional trust instruments. The courts have tended to construe grants of investment discretion in trust instruments narrowly. The settlor, it is said, could not have meant to authorize "speculation" with his property when he granted the trustee discretion in the choice of investments. ${ }^{21}$ The reviewing court sits in judgment on the trustee with the aid of perfect hindsight, ${ }^{22}$ a vantage point from which the temptation to characterize a disappointing investment as "speculative" and to surcharge the trustee may be irresistible. In this way the ancient preoccupation with safety of corpus, designed to protect trust beneficiaries from a recurrence of the South Sea Bubble, continues to supply trust law with its notions of prudence.

The question is thus whether trust law has evolved to the point where it will permit the investment of trust assets in market funds. We shall address that question after first explaining why we believe that legal constraints aside, such investment makes good sense in today's world.

\section{SENSIBLE INVESTMENT STRATEGY FOR A TRUSTEE}

\section{A. Portfolio Design}

The trustee's investment decision involves two conceptually distinct steps. One is evaluating specific assets that might be included in the trust. The other is combining specific assets to form the trust's portfolio, the package of assets constituting the corpus of the trust. The greater emphasis of the law of trusts has been on the first step; less attention has been paid to the design of the portfolio. Yet from the beneficiary's standpoint-which is, of course, the relevant standpoint-what counts is the performance of the portfolio rather than the performance of its individual components. If the value of the portfolio rises from $\$ 500,000$ to $\$ 600,000$, what does it matter to the beneficiary whether this increase resulted from a uniform 20 percent increase in the value of all of the assets in the portfolio or from larger gains in a few of the assets partially off set by losses in others? Conversely, if the portfolio has declined in value, it is of small comfort to the beneficiary to know that one of the components did spectacularly well rather than

21. See 3 Scott, Trusts secs. 227.14, 233.5, at 1848-54, 1933.

22. For an absurd example see In re Chamberlain's Estate, 9 N.J. Misc. 809, 810, 156 A. 42, 43 (1931), where the court, writing in 1931, declared: "It was common knowledge, not only amongst bankers and trust companies, but the general public as well, that the stock market condition at the time... [August 1929] was an unhealthy one, that values were very much inflated, and that a crash was almost sure to occur." 
that all had declined. From the beneficiary's standpoint, the portfolio is the relevant security.

A security, including the composite security that we call a portfolio, has basically only two dimensions, its expected return and its risk. The expected return of a security or other asset is constructed simply by multiplying every possible return by its probability of being the actual return, and then adding up the results of the multiplication. To illustrate, assume that there is a 50 percent probability that a particular stock, the price of which today is $\$ 10$, will be worth $\$ 12$ one year from now, a 40 percent probability that it will be worth $\$ 15$, and a 10 percent probability that it will be worth nothing. ${ }^{23}$ Consequently, there is a 50 percent probability of a $\$ 2$ return, a 40 percent probability of a $\$ 5$ return, and a 10 percent probability of a $-\$ 10$ return, so the expected return is $\$ 2(.5 \times \$ 2+.4 \times \$ 5-.1 \times \$ 10)$. The concept of expectancy used here is the same as that of life expectancy-the summation of the probabilities of living for particular periods of time multiplied by those periods of time.

It is important to note that the expected return generated by a 100 percent chance of obtaining $\$ 10$ is the same as the expected return from a 50 percent chance of obtaining $\$ 20$, or a 1 percent chance of obtaining $\$ 1,000$; it is $\$ 10$. Yet people are not indifferent among the various ways of combining uncertainty and outcomes to yield the same expected return. At least where sizable sums are involved, most people have an aversion to risk. In choosing among securities that have identical expected returns, the risk-averse investor will always choose the one that is generated with the least uncertainty unless the prices of the others are reduced to compensate him for bearing a greater risk, which will have the effect of increasing the expected returns of the riskier securities.

The prevalence of risk aversion in investing is illustrated by the normally lower rate of return on bonds compared to the common stock of the same company. Suppose that the expected return (dividends plus appreciation) on a company's common stock is 10 percent. If investors were risk neutral-if they derived the same utility from identical expected returns however different in riskiness-they would demand 10 percent interest on the company's bonds as well. True, there is less risk to being a bondholder since he has the cushion of the equity shareholders, who would have to be wiped out completely before he could lose his

23. To simplify analysis, assume that no dividends will be paid during the course of the year. The expected return of a stock includes, of course, both price appreciation and dividends. 
interest. But this is offset in an expected-return sense by the fact that the bondholder cannot earn more than the interest rate specified in the bond. Thus, the difference between a company's bond interest rate and the (higher) expected return to owners of the common stock is simply the compensation to the stockholders for the extra risk that they bear.

It follows that there should also be a systematic difference between the expected returns of common stocks that differ in their riskiness. Suppose the expected per-share returns of two stocks $(A$ and $B$ ) are the same, $\$ 2$; but for $A$ the expected return is a combination of a 50 percent probability of no return and a 50 percent probability of a $\$ 4$ return, while for $B$ the expected return is a combination of a 50 percent probability of a $-\$ 6$ return and a 50 percent probability of a $\$ 10$ return. Although we have said that the difference in risk should make risk-averse investors prefer $A$ at the same price, and therefore that $B$ 's price will be bid down below $A$ 's, there is an important qualification, which derives from the important distinction, introduced earlier, between a portfolio and its component securities. Suppose there is another stock $(C)$ which, like $B$, has an expected return of $\$ 2$ resulting from a combination of a 50 percent probability of a $-\$ 6$ return and a 50 percent probability of a $\$ 10$ return, and the only difference between this stock and $B$ is that the fortunes of the two stocks are reciprocal, so that when $B$ does well $C$ invariably does poorly and vice versa. That is, there is a 50 percent probability that $B$ will yield a $-\$ 6$ return, and $C$ will yield a $\$ 10$ return, and a 50 percent probability that $B$ will yield a $\$ 10$ return, and $C$ will yield a $-\$ 6$ return. Then a portfolio composed of $B$ and $C$ will be less risky than a portfolio composed solely of $A$ even though $A$, considered in isolation, is less risky than either $B$ or $C$. In these circumstances, there is no reason for the investor to insist on a risk premium for holding $B$ and $C$ in his portfolio for their risks cancel and the portfolio itself is risk-free.

In a world where the risks of different common stocks were negatively correlated with one another as in the preceding example, there would be few if any differential risk premiums among common stocks. Less obviously, this would also be true if instead of the risks of common stocks being negatively correlated they were uncorrelated, i.e., random, for in a portfolio consisting of many different common stocks the randomly distributed risks of the securities in the portfolio would tend to cancel out, producing a riskless portfolio. To see why this is so, observe that while the risk of death faced by each individual in the country is nonnegligible, the country's death rate-the experience of the "portfolio" consisting of all individuals-is extremely stable. It is, in 
fact, much more stable than the stock market. This suggests that the risks of different common stocks are neither negatively correlated nor random but in fact have a strong positive correlation.

Clearly, to the extent that the risk of one common stock is positively correlated with the risk of another common stock-to the extent in other words that the stocks move together-a portfolio consisting of the two stocks will be as risky as the average of the two stocks. And if in fact the risks of most stocks are positively correlated, as they plainly are since otherwise the stock market as a whole (the "market portfolio") would not fluctuate as dramatically as it does, it will be impossible to construct any portfolio that eliminates the risk associated with each component stock. It is therefore necessary for purposes of portfolio design to distinguish between two components of risk. One is the component that is positively correlated with the risk of the whole flock of securities, the market. This risk cannot be eliminated simply by adding more and more securities. The other component is risk that is negatively correlated or uncorrelated with the risk of the market as a whole and can therefore be diversified away. This explains why diversification is an important goal of portfolio design. It allows one to get rid of a form of risk that is uncompensated and hence is a deadweight loss to the investor who is risk averse. But it does not eliminate all risk; some risk, as we have seen, is simply undiversifiable, and to bear that risk the investor (whom we assume is risk averse) will insist on compensation. Not only can this component of risk not be reduced or eliminated by diversification, but any attempt to reduce it will impose a cost on the portfolio that is distinct from the purely administrative costs incurred in achieving diversification. Because systematic risk-as we may call the risk component that is positively correlated with the risk of the market as a whole-is also compensated risk, the portfolio manager who wants to reduce it must be prepared to pay a price in the form of a lower expected return.

If this analysis is correct, it should be possible to array securities according to their systematic risk and to observe higher rates of return for the riskier stocks. The array has been constructed, the rates of return measured, and the predicted relationship between systematic risk and return found. Stocks that differ in systematic risk have been found empirically to differ in expected return and the correlation between systematic risk and return has been found to be positive as expected. ${ }^{24}$

24. The evidence is summarized in James H. Lorie \& Mary T. Hamilton, The Stock Market: Theories and Evidence chs. 11-12 (Homewood, Ill., 1973). Incidentally, the Lorie and Hamilton book is an excellent introduction to the modern theory of finance on which our 
Since systematic risk is, as we have explained, that portion of a security's total risk that is positively correlated with the movement of the market as a whole, it should be possible to measure systematic risk by comparing the fluctuations of the security with those of the market. Take a security that on average has risen 10 percent when the market has risen 10 percent and has declined 10 percent when the market has declined 10 percent. Its systematic risk (based on past experience) would be equal to that of the market: in the language of finance it would have a "beta" of 1 , beta being the riskiness of the security in relation to that of the market as a whole. If the security rose 20 percent when the market rose 10 percent and fell by 20 percent when the market fell by 10 percent, its beta would be 2, and if it rose by only 5 percent when the market rose by 10 percent and fell by 5 percent when the market fell by 10 percent, its beta would be $.5 .^{25}$ of course, no security will actually move in perfect lock step with the market. But we are not interested in that portion of the stock's variance that is uncorrelated with the movement of the market as a whole. The random variance can be eliminated through diversification; hence it is not compensated. Only the systematic risk-the portion of total risk measured by a stock's beta-is compensated, because only it cannot be diversified away. Accordingly, while a stock having a higher than average beta will have a higher than average expected return, a stock that has a greater overall risk but a lower beta-a stock that moves a lot but not in step with the market as a whole-will have a lower expected return notwithstanding its greater overall risk.

But why, the reader may ask, should stocks differ in their riskiness, both systematic and random? The reasons are not difficult to understand. For example, suppose a company has a high ratio of long-term debt to equity in its capital structure. A decline in the firm's gross revenues will hit the equity shareholders harder than if they did not have a heavy fixed expense of debt service. The stock of such a firm will tend to have a high beta, because any development that tends to affect adversely the business world (and hence stock market) as a whole, such as an unanticipated fall in aggregate demand, will tend to affect this company even more adversely. Conversely, should the market as a whole rise (due, say, to an increase in aggregate demand), this

discussion is based. See also Modern Developments in Investment Management: A Book of Readings, James H. Lorie \& Richard Brealey, eds. (New York, 1972).

25. If the stock rose when the market fell, and vice versa-if in other words its beta was negative-it would be highly prized by the risk-averse investor since its inclusion in the investor's portfolio would reduce the risk of the portfolio. This is stock $C$ in the example on p. 8 supra. Such examples are rare. 
company will tend to do better than firms having average amounts of debt since the costs of debt service are fixed. As an example of diversifiable risk consider a company engaged in prospecting for uranium. Its fortunes will tend to rise and fall with its success or failure in locating uranium deposits, an uncertain process but one unlikely to be systematically related to the movements of the stock market as a whole. It may be a very risky stock, but its beta may be no higher than average.

We are now prepared to suggest some fundamental principles of portolio design. The first is that-putting to one side for the time being the administrative costs of diversification-the portfolio should be widely diversified in order to squeeze out as much as possible of the risk that is uncompensated and hence that represents a deadweight loss to the (risk-averse) investor. One measure of a portfolio's diversification is its correlation with some broadly based index of investment opportunities, such as the S\&P 500. This measure, however, has given rise to a prevalent misconception concerning the degree of diversification that is optimal. ${ }^{26}$ Thus, because the movements of a portfolio consisting of only 32 (carefully selected) stocks would be 95 percent correlated with those of the S\&P $500,{ }^{27}$ it is sometimes assumed that there is no point in holding a larger portfolio, let alone one that would include 250 or 500 stocks. But this is incorrect. For example, although a portfolio consisting of 50 stocks would have a correlation coefficient well above 90 percent, its expected return would be a range of 4.5 percentage points on either side of the expected return of the S\&P 500 , so that if the S\&P 500 one year rose by 10 percent, the 50 -stock portfolio would be expected to increase by anywhere between 5.5 and 14.5 percent. Even a portfolio consisting of 100 stocks would often differ by as much as 3 percentage points from the performance of the S\&P 500; it takes a portfolio of 200 stocks to reduce that figure to 1 percent. $^{28}$ And even the S\&P 500 is not completely diversified; it is itself only a sample of only one type of asset traded on only one exchange. ${ }^{29}$

The second basic principle of portfolio management that emerges from our analysis is that the portfolio manager, by his choice of the

26. See, e.g., Note, Fiduciary Standards, supra note 2 , at 971 \& n. 67.

27. James H. Lorie, Diversification: Old and New, J. Portfolio Management, Winter 1975, at $25,28$.

28. Id. These numbers depend on precisely how the sample is constructed. It may be possible to get better results using smaller samples. This is a problem on which capital-market analysts are working at this time.

29. We shall have more to say about optimal diversification in Part IV, where we discuss specific investment vehicles for the prudent trustee. 
portfolio's beta (undiversifiable risk), will determine the investor's expected return. Thus he can vary that return, depending on the investor's willingness to bear risk.

The third principle is that the best method of achieving the desired risk/return combination is to adjust the proportions in which either relatively risk-free assets are included in the portfolio, or borrowed money is used to increase the portfolio's holdings. To understand the reasoning behind the third principle, consider as a reference point the hypothetical "market portfolio" consisting of all of the stocks traded on the stock market ${ }^{30}$ weighted by the market value of each company whose stock is represented. The beta of the market portfolio is of course 1 ; and its expected return today is probably about 12 percent. $^{31}$ Suppose the portfolio manager is willing to accept a lower return in exchange for less volatility, say half as much as the market as a whole exhibits. That is, he wants a portfolio that will have a beta of .5. How can he get this? He could of course simply cast out the riskier stocks in the market portfolio until the average beta of the stocks that remained was only .5. But in the process his portfolio would become less diversified, and as we have emphasized several times now risks avoidable by greater diversification are not compensated.

The alternative is to add to the portfolio enough corporate or government bonds or other fixed-income securities, with their typically low betas, to pull the average beta of the portfolio down to .5. This has the advantage of not reducing the diversification of the common-stock component of the portfolio. Notice that we have not suggested replacing the common stocks in the portfolio with bonds having an average beta of .5. The resulting portfolio would be badly underdiversified-it would, for example, be much more exposed to the risk of an unanticipated change in the inflation rate than a portfolio which included common stocks, whose earnings are not fixed in nominal dollar terms. A related point is that bonds added to a common-stock portfolio in order to reduce the portfolio's beta should be selected with a view toward maintaining the overall diversification of the portfolio-it would not do, for

30. There is, of course, more than one stock market. Since, however, roughly two-thirds by value of all stocks publicly traded in the United States are listed on the New York Stock Exchange, that exchange provides a pretty good proxy for the (United States) stock market as a whole, so we shall consider our hypothetical "market portfolio" to be limited to NYSE stocks. Whether a trustee's portfolio should contain additional stocks and other securities is discussed in Part IV of the article.

31. Historically, the expected return to common stocks has been on average about 3 percentage points above the long-term bond rate, which is about 9 percent today. 
example, to hold a portfolio that consisted of $\$ 1$ million invested in a market fund and $\$ 1$ million in General Electric bonds.

A simple method of reducing the portfolio's beta is to add 180-day Treasury bills, which are essentially riskless. However, the return to Treasury bills may be lower (after adjustment for risk differences) than the return to other low-risk fixed-income securities for a reason irrelevant to many trust beneficiaries-the extremely high liquidity of Treasury bills. If this feature is unimportant to the trust beneficiary, the trustee will not want to pay a price for it in the form of a lower return (after adjustment for risk differences) than he could get on a different type of security.

What if the trustee desires a higher expected return than that of the market as a whole? (We consider later whether any trustee could properly entertain such an aspiration.) He can get it by borrowing money to buy additional securities for the trust. As an extreme example, suppose that the trustee of a $\$ 500,000$ trust borrows $\$ 500,000$, thus giving him $\$ 1$ million in trust assets which he invests in a fund holding the market portfolio; he pays 9 percent interest on the loan; and the expected return on the market portfolio is 12 percent. His expected rate of return, which is equal to the expected return of the trust portfolio (.12 $X \$ 1$ million $=\$ 120,000)$ minus his interest costs $(.09 \times \$ 500,000=$ $\$ 45,000$ ) divided by the original corpus of the trust, will be 15 percent $(\$ 120,000-\$ 45,000=\$ 75,000 \div \$ 500,000=.15)$. This is higher than the market rate, but the beta of this portfolio is higher than the market's beta too. If, for example, the market declined by 10 percent, the trust portfolio would be worth only $\$ 900,000$ (we ignore the interest cost of the borrowed money), and since the trust would still owe $\$ 500,000$ to the lender its net assets would be only $\$ 400,000,20$ percent less than before the decline of the market. The trust's beta is thus 2. To be sure, the trustee could have gotten the same "play" by casting out the less risky stocks from the market portfolio until the average beta of the remaining stocks was 2. But in doing so he would have had to sacrifice diversification to a considerable extent. By combining the market portfolio with borrowed money-by using "leverage" in other words-he can increase his expected return to the level that he could expect if he held only the riskier stocks, without sacrificing any diversification.

A discussion of portfolio management, to be complete, would have to pay attention to administrative costs, to taxes, and to the specific circumstances and objectives of the investor. We postpone these important details of portfolio management to Part IV, where we discuss specific investment vehicles for the trustee. 


\section{B. The Fallacy of Stock Picking}

We turn now to the issue that has dominated discussion of the trustee's investment obligations: the choice of the specific assets to include in the trust portfolio. This has two aspects, the choice of classes of assets to include and the choice of specific members of the class.

In principle, anything that has a positive expected return-not just publicly traded securities-might be eligible for inclusion in a trust investment portfolio. Most other assets, however, are unsuitable for one reason or another, and often for more than one reason. Part of their value may inhere in consumption rather than investment (works of art, for example), so the trustee would be paying for something that the beneficiary might not be receiving (the beneficiary might, for example, be a small child, or a Philistine). Some are insufficiently liquid for the purposes of most trusts (real estate equities, common stocks of closely held corporations, patents and copyrights, and partnerships and sole proprietorships come to mind); often these are also assets that are unsuitable for a passive investor such as a trustee both because active supervision and management, utilizing skills that the trustee is unlikely to possess, are required in order to make them productive and because their current market prices cannot be assumed to reflect their true expected value without extensive investigation. Some assets are too lumpy to include in a portfolio of modest size without sacrificing diversification. Thus by a process of elimination one is quickly forced back to publicly traded securities as being in general the most suitable kind of asset to be included in a trust portfolio, ${ }^{32}$ because they have none of these disqualifying features.

The next question is how much picking and choosing the trustee should do within the class of publicly traded securities. We have already assumed that the answer is "not too much," for the fact that extensive search is not required to determine whether asking price fairly approximates actual value is one of the features that distinguishes publicly traded securities from real estate, for example. But our real answer is "none."

Any picking will impose costs on the trust of two sorts. The first comprises the research costs incurred in the selection of specific securities to include in or exclude from the trust and the transaction costs

\footnotetext{
32. We set to one side the problems presented when the trust is created by the transfer of specific assets, other than cash or readily marketable securities, which may be costly to liquidate.
} 
incurred in the buying and selling of shares in accordance with the changing results of the securities analysis. The second kind of cost is the sacrifice of diversification that is entailed by holding substantially less than the market portfolio (stock picking implies selectivity, diversification inclusiveness). For these costs to be worthwhile, stock picking must generate larger benefits in the form of a higher expected return than one could expect to receive from the market portfolio adjusted to impose the same level of systematic risk as the portfolio created by stock picking. The qualification is vital: if the result of stock picking was to create a portfolio that had a beta higher than 1 , the portfolio would have a higher expected return than the market portfolio; however, this would be due not to the portfolio manager's skill as a stock picker but to the higher beta of his portfolio, which could have been achieved without any stock picking-simply by levering the market portfolio up to the same beta.

It may seem virtually self-evident that a skilled investor, who conducts careful research into the conditions and prospects of particular companies and of the economy as a whole, will earn a higher return (correcting for any difference in systematic risk) than the investor who simply "buys the market," blindly investing in the entire stock-market list and never selling a stock when its prospects begin to sour. But, on reflection, this proposition really is not self-evident. There is, to begin with, the inherent difficulty of forecasting the future. Since the value of a stock is mainly a function of its anticipated earnings, and therefore depends primarily on events occurring in the future, it will often be impossible to determine whether a stock is undervalued at its current price without knowing what the future holds. As for the stock that is undervalued because of some characteristic of the company (or of its competitors, suppliers, customers, political environment, etc.) that exists today but is not widely known or correctly understood, the problem is that the underlying information is in the public domain. (If it is not in the public domain-if it is "inside" information-it cannot lawfully be used for purposes of buying or selling stock, and presumably the law has some deterrent effect.) Information in the public domain is equally available to all security analysts. The only way of making money from such information is to interpret it better than the other analysts, and this is not a very promising method of outperforming the market because it requires both that the analyst interpret publicly available information differently from the average opinion of the analyst community and that his deviant interpretations be correct substantially more often than they are incorrect. 
The grounds of our skepticism about the benefits of stock picking may seem conjectural, but there is persuasive evidence to back it up. ${ }^{33}$ A large number of separate studies of the mutual fund industry have found that the funds, despite their extensive employment of security analysts and portfolio managers for the purpose of outperforming the market, do not outperform it. They do no better than the blind "market portfolio." Now it may be argued that the proper comparison is not between all mutual funds and the market but between the most successful mutual funds and the market. But the studies show that there are almost no consistently successful mutual funds. Naturally, some enjoy shorter or longer runs of success, but the degree of success observed is no greater than one would expect if luck, not skill, was indeed the only factor determining the fund's performance.

The study of money managers has focused on the mutual funds because they are required by federal law to report in detail on their performance, thus affording a large data base; but there is every reason to believe that common trust funds, pension funds, and other institutional investors likewise fail to outperform the market portfolio. The economist Paul Samuelson has concluded that there is ample reason for doubting whether even "the best of money managers" are "capable of doing better than the averages on a repeatable, sustainable basis." 34

But the studies support an even stronger conclusion: when brokerage costs and management fees are taken into account, the average mutual or common trust fund yields a significantly lower net return than a broadly based market index such as the S\&P 500. ${ }^{35}$ This comparison was long derided on the ground that the $S \& P 500$ is a hypothetical fund and hence has no administrative costs. Now that there are some real market funds in operation, it is possible to evaluate-and reject-this criticism. The administrative costs of a market fund turn out to be so low (on a $\$ 500$ million portfolio, they would be no more than 11 percent of the costs of conventional management ${ }^{36}$ ) that the net returns of a properly constructed market fund are only trivially differ-

33. The relevant studies are summarized in Lorie \& Hamilton, supra note 24 , ch. 4 . For a representative popular treatment see A. F. Ehrbar, Some Kinds of Mutual Funds Make Sense, Fortune, July 1975, pp. 57, 61-62.

34. Paul A. Samuelson, Challenge to Judgment, J. Portfolio Management, Fall 1974, at 17. 35. Michael C. Jensen, Risk, The Pricing of Capital Assets, and the Evaluation of Investment Portfolios, 42 J. Bus. 167 (1969), summarized in Lorie \& Hamilton, supra note 24, at 91-92.

36. Information supplied by Batterymarch Financial Management Corporation. 
ent from those of the hypothetical market portfolio. ${ }^{37}$ The administrative costs are low because the management of a market fund does no securities analysis and very little trading.

Thus we may conclude that market funds are likely to yield higher net returns to the investor (after adjustment for risk) than conventional, stock-picking funds. In addition, they are much better diversified.

Perhaps the most difficult point to understand and accept in the criticism of stock picking is that the portfolio manager has nothing to gain from trying to weed out of his portfolio the obvious "dogs"-the bankrupts like Penn Central, the companies teetering on the edge of bankruptcy like Pan American World Airways. But in fact this weeding out is an unnęcessary and futile endeavor. To begin with, bankrupt companies are not a large element in the market portfolio, for such a portfolio weights each stock by the market value of the company issuing it, and bankrupt companies have a low market value. Consequently the portfolio would not be changed substantially by the trustee's deciding, when he first invested in the market portfolio, to cast out the stocks of bankrupt companies. The more fundamental point, however, is that there is no presumption that the stock of a bankrupt company is a worse investment than the stock of a solvent company. As a consequence of the company's insolvency, the price of its stock will be bid down to the point where its expected earnings, whether from measures that restore solvency or from liquidation, when divided by the current market price of the stock, will yield the same expected return per share as other stocks having the same beta. If it yielded a lower expected return rate than the other stocks, no one would buy it; the price would have to continue falling until its expected return was finally equal to that of the other stocks of its beta.

Suppose bankruptcy occurs after the initial purchase of the market portfolio. If one bought Penn Central stock at $\$ 70$, it is small comfort to know that after the company goes bankrupt its stock will yield a fair return to the investor lucky enough to buy it at $\$ 3$. Does it follow that the investor should have sold Penn Central before it reached \$3? It does not, unless the investor has insight superior to the collective insight of the market, an assumption rendered (in general) untenable by the studies of the mutual funds and trust departments. At every point on its long slide from $\$ 70$ to $\$ 3$, Penn Central stock had an expected rate of return equal to that of the other stocks of the same beta. If investors

37. Alexis L. Belash, Index-Matching: Applying the Efficient Markets Theory, 113 Trusts \& Estates 292, 294 (1974). 
had had perfect foresight, there would not have been a gradual decline from $\$ 70$ to $\$ 3$; indeed the stock would never have been selling at $\$ 70$ in the first place. If we cannot fault investors for having paid $\$ 70$ for the stock, neither can we fault them for having failed to sell when it fell to $\$ 60$, and to $\$ 50$, and to $\$ 30$, for at every point the further decline of the stock was not foreseen-else it would have plummeted at once rather than gradually.

Our conclusion is that the trustee's rational strategy-certainly $a$ rational strategy for him to adopt-is to buy shares in a mutual fund or other investment vehicle that holds the market portfolio-a market fund-and then combine those shares either with borrowing, if he wants more "play" than the market portfolio, or with some relatively riskless asset such as Treasury notes if he wants less. (Alternatively there might be a different fund for each different combination, and the trustee would simply pick the fund that suited his risk/return objectives.) This would enable him to maximize diversification, minimize administrative expense, and get whatever level of systematic risk (and hence of expected return) is appropriate in light of the objectives of the trust. Our conclusion assumes, of course, that a suitable investment vehicle is available, an assumption we consider in Part IV.

We anticipate the objection that if all investors adopted the passive "buy-the-market-and-hold" strategy, the strategy would become irrational. There would be enormous gains from stock picking since no one would be gathering or interpreting the information necessary to value stocks correctly in terms of their anticipated earnings. This is correct, but there is little danger that even if all trustees adopted the passive strategy, which is not likely, that strategy would fail. There would still be many other investors, they would continue to search out undervalued stocks to buy and overvalued stocks to sell, and their activities would make it unnecessary and unprofitable for trustees to do any picking.

\section{THE PROPRIETY OF THE "BUY-AND-HOLD" APPROACH UNDER TRUST-INVESTMENT LAW}

The detailed rules of trust-investment law, properly interpreted and applied, in our view establish the prudence of the "buy-and-hold" investment strategy described in the preceding part of this article.

\section{A. The Duty of Nondelegation}

Courts of equity have long insisted that a trustee not delegate important aspects of the administration of his trust such as the selection 
of trust investments. ${ }^{38}$ At its most innocuous the nondelegation rule is merely a principle of economy, sparing the trust from having to pay twice for the same services. But the thrust of the rule is deeper. It imposes liability on the trustee for an act of his agent that would have been a breach of trust had the trustee himself performed it. ${ }^{39}$ Some trust functions are acknowledged to be delegable and for these the trustee will not be charged with the wrongs of his agent. But there has been considerable difficulty in deciding which is which. As codified in the Restatement of Trusts (Second), the rule is that the trustee may not "delegate to others the doing of acts which the trustee can reasonably be required personally to perform." 40 The authorities have tried to distinguish so-called discretionary functions that require the trustee's personal attention from ministerial ones that do not. Yet because "even the most menial of tasks involves some discretion," 1 that test has not proven very helpful. Hence when a stockbroker or lawyer or whoever has erred or stolen, courts have to decide whether on the facts it was reasonable for the trustee to have deputed him for the particular task.

Some cases purport to treat improper delegation as itself an actionable wrong: conduct that would not have been in breach of trust had the trustee himself performed it becomes actionable when performed by the agent. The trustee "becomes a guarantor and is responsible for any loss that may have resulted, whether or not such loss can be shown to be the result of the delegation ...."42 As applied to trust investments, that theory would leave the trustee liable for every loss, however reasonable the investment when made. His breach of the duty of nondelegation would transfer the risk of the market from the trust to the trustee.

In recent times the nondelegation rule has fallen into deserved disfavor. The duty of prudence that governs all trust administration requires that the trustee use appropriate care in the selection and supervision of agents, and nothing more is needed. The English Trustee Act

38. Restatement of Trusts (Second) sec. $171 \&$ Comment $b$ (1957). The basis of the rule is not altogether clear. What is clear is that since a trustee may not resign his trust without court approval, he is under a duty not to delegate the trust in its entirety. See 2 Scott, Trusts secs. $106,171.1$, at $836,1389$.

39. E.g., In re Hartzell's Will, 43 Ill. App. 2 d 118, , 192 N.E.2d 697, 709-10 (1963).

40. Restatement of Trusts (Second) sec, 171 (1957).

41. William L. Cary \& Craig B. Bright, The Delegation of Investment Responsibility for Endowment Funds, 74 Colum. L. Rev. 207, 224 (1974) (emphasis in original).

42. Meck v. Behrens, 141 Wash. 676, 685, 252 P. 91, 95 (1927); see Annot., 50 A.L.R. 214 (1927). Speaking of the trustee who delegates the entire administration of the trust, Scott writes: "He is not only liable for losses resulting from the negligence or other improper conduct of the person to whom he committed the administration of the trust, but also for any losses resulting from the acts of that person." 2 Scott, Trusts sec. 171.1, at 1390. 
of 1925 all but eliminated the nondelegation rule, ${ }^{43}$ and leading American opinion is hostile. ${ }^{44}$ Nevertheless the rule persists, and its application to trust investment is thought to be clear. The Restatement declares flatly: "A trustee cannot properly delegate to another power to select investments." 45 Yet as a practical matter the duty of nondelegation is widely evaded in modern trust administration. When the investment advisor "recommends" and the trustee routinely "decides" to follow the advice, the trustee in reality is delegating the selection of investments.

\section{Application to Conventional Investment-Company Shares}

Some trusts, especially pension trusts, are large enough to create their own market portfolio, but most trusts would have to pool their funds with those of other investors in order to pursue the strategy at reasonable cost. The commonest means of pooling available to smaller investors is the purchase of shares in an investment company (mutual fund), so the first question we must consider is whether trust investment in mutual-fund shares violates the trustee's duty of nondelegation.

In 1931, when the American mutual-fund industry was still in its infancy, E. C. Lukens, the first writer to consider the point, concluded in a brief article that the nondelegation rule barred trust investment in mutual fund shares. The trustee would be delegating to the investment company both the "possession" of the trust corpus and the power to select investments. ${ }^{46}$ Bogert's treatise in 1935 followed Lukens without discussion, ${ }^{47}$ and in 1938 the Supreme Court of Oregon decided the first case on the point, citing both writers and holding that a trust purchase of investment company shares was improper. ${ }^{48}$

In $1945 \mathrm{M}$. A. Shattuck, a well-known practitioner and writer in the trust field, published what was to become an influential article in support of trust investment in mutual funds. He emphasized that railroads, banks, and insurance companies, in which trustees commonly invest, "not only conduct a specific business enterprise, but also very often

43. 15 \& 16 Geo. V, c. 19 sec. 23(1); see Gareth H. Jones, Delegation by Trustees: A Reappraisal, 22 Modern L. Rev. 381 (1959); Paling, The Trustee's Duty to Act Personally, 125 New L.J. 56 (1975).

44. See William F. Fratcher, Trustees' Powers Legislation, 37 N.Y.U.L. Rev. 627, 660 (1962); cf. Cary \& Bright, supra note 41; see also Note, Trustee's Power to Delegate: A Comparative View, 50 Notre Dame Lawyer 273 (1975).

45. Restatement of Trusts (Second) sec. 171 Comment $b$ (1957).

46. Edward C. Lukens, Investment Trusts as Trust Investments, 79 U. Pa. L. Rev. 266, 268-69 (1931).

47. Bogert, Trusts sec. 679 , at $2039 \&$ n. 75 (1935 ed.).

48. Marshall v. Frazier, 159 Ore. $491,517-18,532-33,544,80$ P.2d 42, 52, 58, 81 P.2d 132, 135 (1938). 
conduct an investment enterprise." 49 Lukens himself had recognized this point and confessed himself unable to guess "just where the law will eventually draw the line."50

In truth the line is a nonsensical one in any jurisdiction that permits trustees to invest in common stock. A trustee's purchase of shares in a company entails his "delegating" the management of the company to its officers and directors. This, indeed, was the basis of the rule in New York and elsewhere in the last century forbidding trustees to invest in company shares. ${ }^{51}$ From the standpoint of the nondelegation rule an investment company's business of trading in the stocks of other companies seems not materially different from a department store's business of trading in merchandise. Indeed, because the changes in a mutual-fund portfolio are reported quarterly and because the Investment Company Act of 1940 requires that major changes in investment policy be approved by the shareholders, "the trustee purchasing an investment company share is in a far better position to know what he is buying than when he buys a share of a commercial or industrial corporation." 2

One could still object to trustee investment in investment-company shares on the ground "that the acts [the company] does are those which a trustee has traditionally done himself," 33 that is, the selection of individual investments. But to this it could be replied, first, that the trustee's initial selection of a particular investment company, and his continuing review of its performance in order to decide whether to retain the shares, required the exercise of his discretion and should therefore "be regarded as a discharge of the duty to invest . . .," and, second, that through the mutual fund medium the trust secured a benefit of considerable value-the superior diversification otherwise available only to the largest trusts. 55

In 1947 an Ohio probate court declined to follow the Oregon precedent, endorsing instead Shattuck's view of the delegation question. "This Court is unable to distinguish in this respect [i.e., delegation] between the powers that are exercised as customary functioning by the

49. Mayo A. Shattuck, The Legal Propriety of Investment by American Fiduciaries in the Shares of Boston-type Open-end Investment Trusts, 25 B.U.L. Rev. 1, 9 (1945).

50. Lukens, supra note 46 , at 270.

51. E.g., King v. Talbot, 40 N.Y. 76, 88 (1869).

52. Alec B. Stevenson, Investment Company Shares: Their Use by Trustees, 85 Trusts \&

Estates 39, 47 (1947), citing Investment Company Act of 1940, 15 U.S.C. sec. 80a-13.

53. Casenote, 60 Harv. L. Rev, 1360 (1947); Stevenson, supra note 52, at 48.

54. Casenote, 34 Minn. L. Rev. 163, 165 (1950).

55. Casenote, supra note 53, at 1361; Alec B. Stevenson, Investment Company Shares: Their Place in Investment Management, 84 Trusts \& Estates 611, 618-19 (1947). 
management of banks, insurance companies, and of any industrial enterprises that have investment portfolios."56 The opinion was affirmed on appeal, 57 and endorsed by commentators. ${ }^{58}$ The question has not since been litigated, ${ }^{59}$ doubtless for three reasons. First, in nearly half of the states legislation has been passed authorizing trustees to invest in mutual funds. ${ }^{60}$ Second, clauses authorizing such investments have found their way into standard-form trust instruments ${ }^{61}$ and have been adopted by trust settlors under the guidance of estate planners $^{62}$ to remove any doubt. Third, the current of professional opinion has been running strongly enough in favor of the view that such investments meet the standard of prudence ${ }^{63}$ to discourage potential litigation. ${ }^{64}$

56. In re Rees' Estate, 53 Ohio Abs. 513, 536, 87 N.E.2d 397, 410 (Ohio Probate Ct., Cuyahoga C'ty, 1947).

57. 53 Ohio Abs. 385, 85 N.E.2d 563 (Ohio App. 1949).

58. Casenote, supra note 53; Casenote, supra note 54; Stevenson, supra note 52, at 141 , 148-49.

59. But see In re Flynn's Estate, 205 Okla. 311, 237 P.2d 903 (1951), assuming the prudence of trust investment in "well-managed investment trusts ...."

60. See the citations collected in 3 Scott, Trusts sec. $227.9 \mathrm{~A}$, at 1833 n. 2. Many of these are enactments of the Model Prudent Man Rule Statute, which was amended to authorize the purchase of shares in investment companies registered under the Investment Company Act of 1940. See Shattuck, supra note 13, at 508-9.

The new federal pension reform law invites pension trusts to invest in mutual funds. ERISA sec. 401(b)(1).

Aided by statute, corporate fiduciaries now operate so-called common trust funds pooling the investment assets of small trusts. These are in effect in-house mutual funds.

61. E.g., James P. Johnson, A Draftsman's Handbook for Wills and Trusts Agreements sec. 511, at 470 (1961) (trustees empowered to invest in "interests in trusts, investment trusts and common trust funds, without being limited by any statute or rule of law concerning investments by trustees ...").

62. A national survey of 800 attorneys and trust officers taken in 1949 (before enactment of most of the statutes cited supra note 60) discovered that "only one out of ten lawyers and trust officers, do buy investment company shares without specific language in the trust instrument; four times as many lawyers and three times as many trust officers (38\% of all respondents) do so with specific language." Alec B. Stevenson, Survey Reveals Trustees' and Attorneys' Interest in Investment Company Shares, 89 Trusts \& Estates 228, 253 (1950) (emphasis in original).

63. E.g., Cary \& Bright, supra note 41 , at 224 ("an investment now considered to be proper almost everywhere"). See also authorities cited supra notes 49 through 60.

As early as 1950 a prominent Illinois practitioner in the field wrote:

If a trustee in Illinois has already invested in shares of an investment trust and if he faces litigation seeking to surcharge him for his action in that regard, and if $I$ had the choice as to which of the two parties I would prefer to represent, I would put myself on the side of the trustee, feeling that thereby I would be more likely to be on the successful side of the case.

William H. Dillion, May Trustees Invest in Investment Trusts? 89 Trusts \& Estates 396, 397 (1950).

The statutes cited supra note 60 are relevant to this point: when nearly half the states enact legislation explicitly authorizing trust investment in mutual funds and none explicitly forbids it, 


\section{Application to Market Funds}

We do not think the trustee's risk of being held to have violated the nondelegation rule is greater when the mutual fund in which he invests holds the market portfolio than when the fund engages in conventional stock picking. Indeed, we think the risk is smaller. The managers of such a fund buy or sell securities according to a predetermined plan, announced in the prospectus and not alterable without notice to and approval of the shareholders. Because the managers do not exercise discretion by evaluating specific securities in order to decide whether to buy or sell them, there is actually less delegation of a judgmental function by the trustee than in the case where he purchases shares in a conventional mutual fund. In effect, the market fund simply executes the trustee's decision to hold a market portfolio. Its role is closer to that of a broker hired to execute the trades ordered by the trustee than that of a conventional mutual fund to which the trustee delegates the selection of the individual securities that constitute the portfolio.

At the outset of our discussion of the application of the nondelegation rule to mutual funds, we noted that the desire to spare the trust from paying both the trustee and his agent for the same service was a legitimate factor behind the rule. That concern troubled the early discussion of trustee investment in conventional mutual funds. Shattuck, writing before the proliferation of no-load mutual funds, argued lamely that the sales load corresponded to "market spread" between bid and asked prices on ordinary securities plus brokerage commissions. ${ }^{65}$ But brokerage commissions are lower than load charges, and in any event the fund itself has to pay brokerage charges on its trades. We assume that in an era of widely available no-load funds, it could well be a breach of trust (with damages measured by the amount of the load charge) for a trustee to buy a load fund. To the further objection that

one may fairly infer that the statutes are declaratory of a common opinion of the prudence of the investment form.

The Restatement of Trusts (Second) sec. 227, Comment $n$ (1957), however, remains noncommittal: "Apart from statute it would seem to be not improper for a trustee to make such an investment, provided that it is a prudent one, and that such an investment does not involve any delegation by the trustee of his powers." Scott, the Restatement reporter, states in his treatise: "The question whether a trustee can properly invest in ... shares in an investment company is in most states an undecided question." 3 Scott, Trusts sec. 227.9A, at 1833.

64. Some indication of the prevalence of trust investment in mutual fund shares is the extent of the litigation and the literature conceming the allocation of mutual fund capital gains dividends between successive trust beneficiaries. See 3 Scott, Trusts sec. 236.14, at 2016 \& n. 9; cf. Annot., 98 A.L.R.2d 511 (1964).

65. Shattuck, supra note 49 , at 21 . 
both the trustee and the fund levy management charges, Shattuck could answer only that the extra diversification was worth the extra price. ${ }^{66}$

A market fund offers not only superior diversification but also great cost savings, by eliminating research costs and minimizing turnover (and hence brokerage commissions). Batterymarch Financial Management Corporation, which manages a market fund, has estimated that the annual cost (management fee, brokerage commissions, and custodial fees) of a $\$ 500$ million fund under conventional management would be equal to .55 percent (i.e., a bit more than one-half of one percent) of the fund's assets; the corresponding figure for a Batterymarch market fund of the same size would be only .06 percent of the fund's assets. Even if the largest market fund available had only $\$ 25$ million in assets, the annual cost would be only .18 percent of the fund's assets, still a low charge (less than two tenths of one percent), and plainly a reasonable one for the trustee who is not in a position to create his own market portfolio at the same or a lower cost.

\section{B. Prudent Investment}

\section{The Focus on Individual Securities}

The courts characteristically apply the prudent-man standard to each investment decision of the trustee rather than to the trust portfolio as a whole. In the recent Spitzer case, which has caused some unwarranted concern in trust circles, the New York Court of Appeals said: "The fact that this portfolio showed substantial overall increase in total value during the accounting period does not insulate the trustee from responsibility for imprudence with respect to individual investments for which it would otherwise, be surcharged ...."67 As we shall see, the

66. Id. at 22 .

67. Reported as In re Bank of New York [hereinafter cited as Spitzer], 723 N.E.2d 700, 703 (N.Y. 1974) (citations omitted).

In Spitzer, a guardian ad litem appointed to represent the remaindermen interested in a bank common trust fund contested the bank's periodic accounting for a four-year interval between 1964 and 1968. Although the entire fund recorded a gross gain of $\$ 1,700,000$, there were losses amounting to $\$ 238,000$. The guardian challenged the prudence of four of the bank's securities investment decisions. On the bank's motion, the trial court granted summary judgment dismissing the objections to two of the four, and denied the motion for summary judgment as to the other two decisions (involving shares of Parke, Davis and Boeing on which the trust had lost over $\$ 45,000)$. Both sides appealed. A divided intermediate appellate court sustained the bank's motion for summary judgment on all four investments, 43 App. Div. 2d 105 (1974), and the court of appeals affirmed unanimously, supra. The dissenters in the intermediate court thought it was a telling argument that "[w] hatever accretion there was to the trust might just as well be credited to a generally rising market as to a claimed watchful and prudent management; one shudders to think what could have happened in a period of decline." 43 App. Div. 2d, at 108. The case was in the appellate court before the bank had put in any evidence, 
individual-investment standard continues to make good sense in the context in which it was developed. But when the purposes of the standard are properly understood, its inapplicability to the separate components of market portfolios becomes apparent.

The individual-investment standard derives from two distinct principles of trust law. One is the rule, codified in Section 213 of the Restatement, that a trustee cannot reduce his liability for wrongful investments that have resulted in losses by setting off profits earned on other trust investments. ${ }^{68}$ The justification for that rule is that the gains are not the trustee's to set off against his personal liability for wrongful conduct-they belong to the trust. Section 213 pertains only to wrongful investments. When losses result from prudent investments, the trustee is allowed to charge them to the trust and hence in effect to net the trust's investment losses and gains. Usually when the courts refer to their duty to review individual investments they are enforcing the rule against netting the losses from wrongful investments. ${ }^{69}$

To be sure, courts have also examined trust investments on an individual basis for the purpose of deciding what is wrongful (imprudent). But since in traditional trust investment strategy the trustee selects investments on an individual basis, it is reasonable for courts to review them on that basis. Even then, the judicially developed duty of the trustee to diversify the investments of the trust ${ }^{70}$ reflects the courts' awareness that factors extrinsic to a particular security bear on its prudence as a trust investment. As the New York Court of Appeals said in the Spitzer case:

The record of any individual investment is not to be viewed exclusively, of course, as though it were in its own water-tight compartment, since to some extent individual investment decisions may properly be affected by considerations of the performance of the fund as an entity, as in the instance, for example, of individual security decisions based in part on considerations of diversification of the fund or of capital transactions to achieve sound tax planning for the fund as a whole. The focus of inquiry, however, is nonetheless on the individual security as such and factors relating to the entire portfolio are to be weighed only along with others in reviewing the prudence of the particular investment decisions. ${ }^{71}$

and the opinion does not disclose on what basis the dissenters thought that the bank's management of the fund "might with equal efficiency have been carried out ... by the doorman on duty." Id.

68. Restatement of Trusts (Second) sec. 213 (1957).

69. For example, the language from Spitzer quoted in the text at note 67 supra is followed by $a$ citation to Scott's account of the wrongful-investment rule. (1969).

70. Restatement of Trusts (Second) sec. 228 (1957); see also Annot., 24 A.L.R.3d 730

71. 323 N.E.2d 700, 703. 
When, however, the trustee's investment strategy is to hold a market portfolio, which implies that he will not attempt to evaluate the merits of the individual securities in the portfolio, the rationale of the individual-investment standard is inapplicable, and we would not expect the courts to apply the standard to him. Since the trustee in such a case is not selecting individual stocks and is passing on to the trust the savings that result from his abstention from a conventional stock-picking investment strategy, the appropriate standard of prudence should be that of the reasonableness of the market portfolio in the light of the risk/return objectives of the particular trust. If the risk/return characteristics of the portfolio are at least as attractive as those of an individual security that would be considered a prudent investment for the trustee, there is no basis in logic-and we believe there is none in the law-for inquiring into the prudence of the individual securities constituting the portfolio.

Legal objections based on the individual-investment standard are especially weak when the trustee's implementation of the "buy-andhold" strategy takes the form of purchasing shares of a market fund. Since the shares of conventionally managed mutual funds are considered (in general) prudent investments, the shares of a properly designed and administered market fund should be considered a fortiori prudent if the analysis in Part II of this article is sound. The same argument applies to a common trust fund that holds a market portfolio.

\section{2. "Wrongful" and "Speculative" Investments}

The trustee who pursues the "buy-and-hold" strategy will all but inevitably be acquiring an interest in some stocks that if individually selected would be characterized as wrongful or speculative and hence as imprudent for trust investment. If, for example, the trustee were to match the S\&P 500, he would be buying into such momentarily troubled firms as Chrysler, Consolidated Edison, W. T. Grant, Rapid American, and Pan American. The courts may be tempted to apply conventional trust-law notions of prudence and say to the trustee that he should have weeded out of the index the shares in obviously shaky companies.

In our view, however, the standard of review for an investment in a collective entity ought to be the collectivity, and we would expect the courts so to hold. The trustee who bought Ford Motor shares in 1958 was not surcharged for the speculative component of the enterpriselaunching the Edsel-and a trustee who buys shares in a conventionally managed mutual fund is unlikely to be surcharged because one of the many component securities of the fund portfolio would, standing alone, be a questionable trust investment. 
It may be objected that the trustee who bought shares in Ford or in a managed mutual fund did not have the choice of avoiding the speculative component. To buy Ford the trustee had to accept the Edsel part of the enterprise as well, and the managed mutual fund was also offered to him on a take-it-or-leave-it basis. A trustee buying shares of a market fund is arguably in the same position; but what of the trustee who creates his own market portfolio and therefore could exclude specific securities? In our view, he should not be required to exclude the stocks of companies that are bankrupt or in danger of becoming bankrupt, because there is no basis for believing that such stocks are characteristically overvalued. As the danger becomes perceived, their prices will be bid down to the very low levels at which the expected return to the investor is equal to that of other stocks of the same beta. The time to sell stock in a company headed for trouble is before the market discovers the trouble and discounts the price of the stock accordingly. But to beat the market to the punch is precisely what a trustee or other institutional investor cannot be expected to do with any consistency. Once the price of the stock has already been bid down in recognition of the company's parlous state, it is too late to expect to benefit from selling it.

Of course, even though the stock of a bankrupt company may have the same expected return as other stocks of its beta, it may be excessively risky (the stock may have a high probability of soon being worth nothing). But this does not change the analysis. If a stock has a great deal of diversifiable risk, that risk can be eliminated by holding a diversified portfolio and will be by the investor who holds a market portfolio. If a stock has a lot of systematic risk, it will add, though only trivially in the usual case, to the beta of the portfolio, but that component of the portfolio's total risk is also within the portfolio manager's control. He can adjust it upward or downward by combining the market portfolio either with the purchase of less risky assets or with borrowing. ${ }^{72}$

The problem of the inclusion in a market fund of stocks of bankrupt or deeply troubled companies is, in any event, one of small practical importance. A properly designed market fund weights stocks by the aggregate market value of the outstanding shares of the company, and since market value is simply the capitalization of future earnings, stocks of companies having poor earnings prospects will not bulk large

72. Whether a trustee can ever employ leverage without running afoul of the rules of trust law is considered infra p. 33. 
in the fund and a further drop in their prices will have little impact on the value of the fund.

Out of an abundance of caution, however, a trustee who adopts the "buy-and-hold" strategy or a market fund designed for trustees may wish to exclude stocks of firms that are, or are clearly in danger of soon being, insolvent. The identification of such firms should entail minimal research costs-perhaps nothing more than keeping up with Moody's or some other service that evaluates the solvency of major companies. We do not think the weeding out of the insolvent or the likely-to-become-insolvent firms from the market portfolio is necessary to meet the requirements of prudence. But if such weeding can be done at low cost it may be worth doing to minimize legal risk. So saying, we are well aware that such weeding is inconsistent with the fundamental premises of the market-fund approach.

\section{The Duty of Loyalty}

Perhaps the most stringent principle of trust law is that the trustee must administer the trust for the exclusive benefit of the trust beneficiaries. He is forbidden to profit from dealing with the trust property, no matter how reasonable or fair the transaction. ${ }^{73}$ As a corollary of this, a corporate trustee may not purchase shares of its own stock for the trust's account ${ }^{74}$ unless the trust instrument expressly authorizes such a purchase. The question arises, therefore, whether a corporate trustee may buy its own shares pursuant to a "buy-and-hold" strategy. For example, the American National Bank and Trust Company of Chicago is a subsidiary of the Walter E. Heller Company, and Heller is one of the companies on the S\&P 500. If American National Bank as trustee were to create a market portfolio based on that index, should it buy all 500 or should it exclude Heller and buy only 499 stocks? In favor of buying Heller, it can be said that the purchase is mechanical: the bank as trustee would buy Heller stock only in proportion to its value-weighted share of the S\&P 500. But since Heller stock can be excluded from a market portfolio equally mechanically, the bank's implicit decision to include shares of its parent in the portfolio may be thought to fall within the scope of the absolute prophylactic rule. There might be a suspicion that the decision to include the shares of the parent had not been made for the exclusive benefit of the beneficiary but in part to support the parent's share prices or to increase the number of shares

73. 2 Scott, Trusts secs. $170,170.2$, at 1297-99, 1304.

74. See 2 Scott, Trusts sec. 170.15, at 1340, citing inter alia Uniform Trusts Act sec. 7. 
subject to management control for voting purposes. We reluctantly conclude that, in market as in conventional portfolios, the absolute rule against trustee self-dealing forbids the corporate trustee to buy its own shares. We assume, however, that the corporate trustee would not be forbidden to purchase shares in market funds that include modest holdings of its shares in their portfolios; the element of conflict of interest would be too attenuated in such a case.

Since none of the banks or bank holding companies that serve as corporate trustees constitutes by itself a significant fraction of the total market value of listed securities, the exclusion of the shares of the corporate trustee from a market portfolio would not result in a significant departure from optimal diversification.

\section{The Duty to Diversify}

The duty to diversify investments, as codified in the Restatement, requires the trustee "to distribute the risk of loss by a reasonable diversification of investments ..." and-hold investment strategy is thereby enabled to diversify far beyond the level achievable with a managed portfolio and hence is better able to discharge his duty than the conventional trustee.

A pension trust or bank common trust fund may have sufficient assets to create its own market portfolio, but for smaller trusts the only practical opportunity to buy the market is to invest in the shares of a market mutual fund, and even the very large trust may obtain significant cost savings from pooling. ${ }^{76}$ The question therefore arises whether the trustee, who would breach his duty to diversify if he invested all of the trust funds in the shares of one or a handful of enterprises, would likewise be in breach if he invested the trust funds in the shares of an equally small number of investment companies. We think not. Certainly from the standpoint of diversification the trust that holds shares in a single mutual fund that holds a market portfolio is much better protected than if it held shares in a single enterprise, even if that enterprise were itself a "conglomerate" (i.e., diversified) company. The benefits of the mutual fund's internal diversification are passed through to the trust; the trust's risk is diversified down to the level of the mutual fund's.

The harder question is whether a trustee has a duty to diversify among several market funds. At first glance it would seem that the

75. Restatement of Trusts (Second) sec. 228 (1957).

76. See p. 20, supra and p. 30, infra. 
superior diversification achieved by investing in any one market fund would wholly discharge the trustee's duty. To take the simplest example, if several competing investment companies are offering identical or virtually identical portfolios, there would seem to be no gain from spreading the assets of a single trust fund among them. However, there are some risks to putting all of the trust's eggs in one investment company's basket. There is the possibility that the managers of an investment company might loot it-the Equity Funding scandal is a reminder that giant frauds do occur from time to time. Or it could happen that fire or other catastrophe would overtake the offices, records, and securities certificates of one investment company. To spread such risks, it can be argued that the trustee should spread his investments among several mutual funds.

On the other hand, the costs of such diversification may outweigh the benefits. For example, Batterymarch's market fund is offered to fiduciaries on a sliding-fee scale that makes no charge (other than custodial) for trust funds invested above $\$ 100$ million (a dramatic illustration of the economies that can result from abjuring stock picking). Thus even a pension trust with several hundred million dollars to invest would pay a price for diversifying beyond Batterymarch. In such cases there can be no automatic rule. The trustee must balance the gains and costs of diversifying. The Restatement rule protects him well by requiring "reasonable diversification of investments unless under the circumstances it is prudent not to do so." 77

\section{E. A Duty to Buy the Market?}

We began with the question whether trust law would permit the trustee to implement the lessons of capital market research and adopt a buy-the-market investment strategy. We think we should conclude our review of the trust law by warning fiduciaries that they cannot "play safe" by ignoring the new learning and continuing uncritically to put trust money into old-fashioned, managed portfolios. When market funds have become available in sufficient variety and their experience bears out their prospects, courts may one day conclude that it is imprudent for trustees to fail to use such vehicles. Their advantages seem decisive: at any given risk/return level, diversification is maximized and investment costs minimized. A trustee who declines to procure such advantages for the beneficiaries of his trust may in the future find his conduct difficult to justify.

77. Restatement of Trusts (Second) sec. 228 (1957). 
IV. SPECIFIC INVESTMENT VEHICLES AND STRATEGIES FOR THE PRUDENT TRUSTEE WHO DESIRES TO HOLD A MARKET PORTFOLIO

\section{A. Choice of Investment Vehicle}

As already explained, all but the very largest trusts that desire to hold a market portfolio would be better advised to buy shares in a mutual fund that holds such a portfolio or to pool their assets in market common trust funds than to create their own market portfolios. This means that in the short run most trustees will be limited by the range and variety of market funds offered by investment companies and bank trust departments. At present, to the best of our knowledge, the only market funds extant are approximations of the S\&P 500. ${ }^{78}$ Since the S\&P 500 represents 80 percent (by value) of the stocks listed on the New York Stock Exchange, and about two-thirds (again by value) of all of the common stocks traded either in organized exchanges or over the counter in the United States are listed on the NYSE, these market funds offer a well-diversified portfolio of American common stocks. But they do not exhaust the possibilities for diversification. It has been shown that a portfolio which contained corporate bonds in proportion to the ratio of the market value of the bonds of all the companies listed on the NYSE to the market value of all of the common stocks listed on the NYSE would be more diversified than a pure NYSE common stock portfolio. ${ }^{79}$ There would be additional gains from adding stocks traded on other stock exchanges besides the NYSE. We can expect such market funds to come into being and when they do they may be attractive vehicles for trustees but until they do a trustee cannot be criticized for buying shares in one of the existing market funds. Such a fund provides an inexpensive method of achieving a level of diversification very superior to that of existing mutual and common trust funds. If the stock market is too volatile given the objectives of the trust, the trustee can dampen the volatility of his portfolio by placing a portion of the trust assets in relatively risk-free assets as discussed in Part II.

Tax considerations may of course warrant departures from a pure market-portfolio approach. Since (cash) dividends and interest are taxable income to the trust, a market fund-especially one that included

78. It is not necessary to hold all of the S\&P 500 to have a portfolio that moves. in very close step with it. A carefully selected sample of 200 or even fewer firms may offer a close approximation at considerable cost savings. See note 28 supra and accompanying text.

79. William F. Sharpe, Bonds Versus Stocks: Some Lessons from Capital Market Theory, Financial Analysts J., Nov.-Dec. 1973, at 1. 
bonds as well as stocks-would have quite different income-tax consequences from one designed to match an index (if there were one) of tax-exempt municipal bonds or non-dividend-paying stocks. But any attempt to reduce income-tax liability in this manner would sacrifice diversification. The trustee would have to balance diversification losses against tax gains in accordance with the risk preferences of the trust's beneficiaries.

\section{B. Choice of Beta}

Assuming the investment vehicle has been selected, the next task is to select the appropriate level of systematic risk. To be told that the beta of the hypothetical market portfolio consisting of all of the stocks listed on the New York Stock Exchange, weighted by the market value of the corporations issuing those stocks, is 1 , and that the available market funds can be expected to have the same beta, does not tell the trustee whether it is an appropriate level of risk for the trust. That depends on the objectives of the trust, which in turn depend mainly on the circumstances of the trust's beneficiaries. As is well known, the New York Stock Exchange is subject to very wide swings in short periods. In the 1974 bear market, the market fell almost 50 percent, and in the Great Crash 90 percent. As we have seen, the trustee can reduce the beta of his portfolio by combining shares in a market fund with the purchase of low-risk assets such as U.S. Treasury notes. But he pays a price: his expected return is lower.

Since determining the preferred risk automatically determines the expected return, and vice versa, the only choice the trustee has is among risk/return combinations, but the choice is a wide one. The scientific way to make this choice is first to construct a schedule of the anticipated payments from the trust to the beneficiaries during the life of the trust (and on its termination), and then to calculate the likelihood that the trust will be able to meet this payment schedule under various assumptions as to the level of risk and of expected return selected by the trustee. The calculations are technical but straightforward. ${ }^{80}$ Suppose the trust is for the support of an elderly widow, with the remainder to a charity. The trust is the widow's only source of income, and to preserve her standard of living the trustee will have to distribute to her, each year, income (and/or principal) amounting to $\mathrm{X}$ thousand dollars. If the trustee selects a high-risk/high-return investment strategy,

80. Among firms that specialize in making calculations of this sort, we know of Becker Securities Corporation and Dreher, Rogers \& Associates, Inc., in New York City, and Frank Russell Co., Inc., in Tacoma, Washington. 
then, depending on the ratio of the annual distribution to the principal and income of the trust, one year he may not be able to make the distribution without invading principal so deeply as to jeopardize his ability to make future annual distributions. This is the classic case for a low-risk/low-return strategy.

At the other extreme imagine a case where the trust beneficiary is a wealthy individual in a high income-tax bracket who has many other assets conservatively invested. There would be no reason in such a case for the trustee to follow a low-risk/low-return strategy, and indeed it might be appropriate for him to employ leverage to create an expected return higher than that of the market as a whole. We are aware of the traditional rule against a trustee's borrowing money on behalf of the trust. $^{81}$ The rule is based on two policies, neither applicable in the present context. The first is the policy of confining a trustee's activity to investment rather than permitting him to act as an entrepreneur. In most cases where borrowing has been at issue, the trustee was using trust funds to carry on a business. But the trustee who levers a market fund, like a trustee who buys levered common stock, remains a passive investor; he is not at all like a trustee who, for example, uses trust funds to buy and operate a hotel and borrows money to facilitate the transaction. ${ }^{82}$ The second policy is that of limiting the risks that a trustee may take. Obviously, leverage increases the risk of the trust assets, and in many cases it would be utterly imprudent to subject the beneficiaries to such a level of risk. But the proper question is whether the risk is excessive, not whether it is achieved by leverage. It is more prudent to give the trust assets a beta of 1.5 by levering a market portfolio than by limiting the portfolio to common stocks having an average beta of 1.5 , thereby sacrificing diversification. Indeed, the difference between the market portfolio levered to a beta of 1.5 and the individual stock having a beta of 1.5 is of almost metaphysical subtlety, since very often the reason a stock has a high beta is precisely that the company issuing it is highly levered (i.e., has a high proportion of debt in its capital structure).

Most pension trusts will be intermediate between the two examples that we have given of appropriate attitudes toward risk and return. Because employees will have additional sources of support in retirement, such as Social Security, and are accordingly not wholly dependent on the precise level of benefits that they receive from the pension trust, and because in the case of defined benefit plans the employer is obli-

81. 3 Scott, Trusts secs. $191.3,227.6$, at 1587,1816 \& n. 1.

82. As in Sebree v. Rosen, 349 S.W.2d 865, 889-90 (Mo. 1961). 
gated, and in most cases financially able, to make good any deficiencies in the pension trust's ability to make payments to the retirees at the contractually specified pension pay-out level, it would appear that many pension trusts could appropriately, and in the circumstances prudently, choose to assume a relatively high level of risk in order to obtain the relatively high return correlated with it. Such a trust might well be justified in placing all of its assets in a common-stock market fund.

While the individual trustee can vary the systematic risk and hence expected return of the trust by altering the proportion of market-fund shares in the portfolio, it may be substantially cheaper for an investment company to offer a variety of market funds in which the market portfolio is combined with varying amounts of leverage or of less risky assets such as Treasury notes to yield a range of risk/return combinations among which the trustee can choose. We can expect these additional investment vehicles to emerge ${ }^{83}$ as the economic and legal analysis in this article gains support within the trust community.

83. Courts have long deemed it imprudent for a trustee to invest in the shares of new and untried enterprises. See 3 Scott, Trusts sec. 227.6 , at 1816 \& n. 4. That rule would not apply, however, to shares of newly organized mutual funds that invest in established enterprises. Market funds are conduits for investment in the securities of established, exchange-listed firms. For the same reason, when conventionally managed mutual funds were first being recognized as trust investments, it was never suggested that the rule forbidding investment in new and untried enterprises should be applied to them. 